\title{
The Fok1 Vitamin D Receptor Gene Polymorphism and 25(OH) D Serum Levels and Prostate Cancer among Jordanian Men
}

\author{
Manar Fayiz Atoum ${ }^{1 *}$, Dena AlKateeb ${ }^{1}$, Sameer Ahmed AlHaj Mahmoud ${ }^{2}$
}

\begin{abstract}
Background: Prostate cancer (PCa) is one of the most commonly diagnosed neoplasms and the second leading cause of cancer death in men in the Western world. Vitamin D $(1,25$ dihydroxy vitamin $D)$ is linked to many biological processes that influence oncogenesis but data on relations between its genetic variants and cancer risk have been inconsistent. The aim of this study was to determine associations between a vitamin $D$ genetic polymorphism and 25-hydroxyvitamin $\mathrm{D}[25(\mathrm{OH}) \mathrm{D}]$ levels and prostate cancer. Materials and Methods: Genomic DNA was extracted from 124 Jordanian prostate cancer patients and 100 healthy volunteers. Ethical approval was granted from the ethical committee at Hashemite University and written consent was given by all patients. PCR was used to amplify the vitamin D receptor Fok1 polymorphism fragment. 25(OH)D serum levels were measured by competitive immunoassay. Results: All genotypes were in Hardy-Weinberg equilibrium. Genotype frequency for Fokl genotypes FF, Ff and ff was 30.7\%, $61.3 \%$ and $8.06 \%$, for prostate cancer patients, while frequencies for the control group was $28.0 \%, 66.0 \%$ and $6.0 \%$, respectively, with no significant differences. Vitamin D serum level was significantly lower in prostate cancer patients (mean $7.7 \mathrm{ng} / \mathrm{ml}$ ) compared to the control group $(21.8 \mathrm{ng} / \mathrm{ml})$. No significant association was noted between $25(\mathrm{OH}) \mathrm{D}$ and VDR Fok1 gene polymorphism among Jordanians overall, but significant associations were evident among prostate cancer patients (FF, Ff and ff : $25(\mathrm{OH}) \mathrm{D}$ levels of 6.2, 8.2 and 9.9) and controls (19.0, 22.5 and 26.3, respectively). An inverse association was noted between $25(\mathrm{OH}) \mathrm{D}$ serum level less than $10 \mathrm{ng} / \mathrm{ml}$ and prostate cancer risk (OR 35.5 and $95 \%$ CI 14.388.0). Conclusions: There is strong inverse association between $25(\mathrm{OH}) \mathrm{D}$ serum level less than $10 \mathrm{ng} / \mathrm{ml}$ level and prostate cancer risk.
\end{abstract}

Keywords: Prostate cancer - vitamin D - Fokl polymorphism - Jordan

Asian Pac J Cancer Prev, 16 (6), 2227-2230

\section{Introduction}

$\mathrm{PCa}$ is one of the most commonly diagnosed forms of cancer among men in industrialized countries (Nwosu et al., 2001), whose incidence rates are rising rapidly in most countries including low-risk populations (Habuchi et al., 2000). It is a health problem in developed countries because of their greater proportion of elderly men. About $15 \%$ of male cancers are PCa in developed countries compared to $4 \%$ of male cancers in developing countries (Parkin et al., 2001). Prostate cancer incidence increases with age and it is estimated that $80 \%$ of men would be affected by the age of 80 years (Holund, 1980). In Jordan, $\mathrm{PCa}$ is the sixth among Jordanian male cancer which accounted for $7.9 \%$ of male cancers (www.moh.gov.jo).

Vitamin D (the sun-shine vitamin) plays a prominent role in bone and calcium metabolism also has functions in the immune system, central nervous system, epithelial cells, and various endocrine processes (Haussler et al., 1998). It has anticancer effects that are mediated through the vitamin D receptor (Brown et al., 1999), It promote cell differentiation, apoptosis, inhibition of cellular proliferation, angiogenesis and tumor cell invasion (Holt et al., 2009; Luong et al., 2010). VDR activation may regulate directly or indirectly the expression of 100-1250 genes (Yu and Cantorna, 2011; Zhang and Ho, 2011). Vitamin D exerts its biological effects through binding and activating the intracellular VDR, which acts as a liganddependent transcriptional factor in many types of tissues, including the prostate (Miller et al., 1992).

VDR is expressed in over 30 different cell types and located on chromosome 12q12-14 (Wu-Wong, 2007). Consisting of 14 exons and spanning approximately 75 kb long (Crofts et al., 1998). VDR gene encompasses two promoter regions, eight protein-coding exons (namely 2-9] and six untranslated exons (1a-1f) (Baker et al., 1998). Exons 2 and 3 of the VDR gene are involved in DNA binding, and exons 7,8, and 9 are involved in binding to vitamin D (Hughes et al., 1988).

Polymorphisms of the VDR gene potentially affect the receptor binding Of 1,25 dihydroxyvitamin $\mathrm{D} 3$, that may modify vitamin $\mathrm{D}$ biological activity and confer 
susceptibility to prostate cancer (Yin et al., 2009). Oral administration of active vitamin D metabolites delays the recurrence of prostate cancer following primary therapy (Gross et al., 1998). This indicates that active vitamin D metabolites can be effective in slowing the progression of prostate cancer risk.

VDR gene is highly polymorphic and its allele frequencies are highly variable among different races and ethnic groups. More than sixty VDR polymorphisms have been discovered that are located in the promoter, in and around exons 2-9 and in the 3'UTRregion (Peehl et al., 1994). VDR gene variants that are studied include a 5' Fokl site in exon 2 that alters the start codon ( $\mathrm{Li}$ et al., 1999). Correlation between low circulating levels of $25(\mathrm{OH}) \mathrm{D}$ were associated with an increased risk of subsequent earlier onset and more aggressive progression of prostate cancer, especially before the age of 52 (Polek and Weigel, 2002).

The aim of this study is to determine rs 10735810 or Fokl polymorphism on exon 2 within VDR gene among prostate cancer Jordanian males. This polymorphism contain two potential translation initiation (ATG or start) sites (Saijo et al., 1991). A polymorphism has been described in the first start codon which changes the nucleotide sequence to ACG. The f allele contains both ATGs, whereas the F allele has only the second ATG, and thus predicts a shorter VDR protein (Ingles et al., 1998). This study also determined vitamin D level among prostate cancer patients and determine any association between v25(OH) D level and VDRFoklgene polymorphism among prostate cancer patients.

\section{Materials and Methods}

A total of 124 prostate cancer patients were recruited from the urogenital cancer clinic at Al- Basheer Hospital/ Amman (2013-2014)that were histopathologically diagnosed with prostate cancer by specialized pathologists. One hundred age matched control volunteers with no familial history of any cancer were recruited from the Jordanian society. Ethical approval for this study was received from the Institutional Review Board (IRB) at the Hashemite University. Consent forms were signed by all participants before interviewing and sample collection. Plain tubes samples were centrifuged within two hours of sample collection, Serum was separated and stored at $-60^{\circ} \mathrm{C}$ for vitamin D determination. EDTA tubes were used for DNA extraction with in 2-4 hours from collection.

Almost 500 $\mu$ l of serum aliquots were used to measure serum 25(OH) D level using Elecsys vitamin D total assay kit (Roche Diagnostics, Switzerland) by MODULAR ANALYTICSE170 analyzer.

DNA samples were extracted using the Wizard Genomic DNA Purification kit (Promega, USA). DNA samples were amplified using the BIO RAD iCycler with the specific primers that are complementary to Fokl VDR gene

Forward 5'-ACTCTGGCTCTGACCGTG-3' and Reverse 5'-TCATAGCATTGAAGTGAAAGC.PCR was conducted using Go Taq ${ }^{\circledR}$ Green Master Mix DNA, then samples were amplified: Initial denaturation step at $94^{\circ} \mathrm{C}$ for $3 \mathrm{~min}$, followed by 35 cycles of denaturation step at $94^{\circ} \mathrm{C}$ for $90 \mathrm{sec}$ then annealing step at $58^{\circ} \mathrm{C}$ for $60 \mathrm{~s}$ and extension at $72^{\circ} \mathrm{C}$ for 90 s. Finally the refrigeration cycle at $4^{\circ} \mathrm{C}$. Following amplification, SNPs FokI(rs2228570) in VDR gene was detected by restriction enzyme digest using the restriction endonuclease digestion (Jenna Bioscience, Germany) at $37^{\circ} \mathrm{C}$ for two hours. All fragments then visualized on $2 \%$ agarose gel electrophoresis. The expected size of FokI (FF) genotype is 159 bp, FokI (Ff) genotype are $159 \mathrm{bp}+53 \mathrm{bp}+106 \mathrm{bp}$ and for FokI (ff) genotype are $53 \mathrm{bp}+106 \mathrm{bp}$.

Statistical analysis was performed using the Statistical Package for Social Sciences (SPSS) version 20.Chisquare test was used to evaluate case-control differences for FokI genotype distribution among case and control groups. T- test was used to evaluate the significance of difference of mean 25(OH)D levels between case and control groups. The association between FokI different genotypes and prostate cancer risk, vitamin D level and FokI different genotypes were evaluated by calculating the odd ratios (OR) using "Mantel Haenszel"method and $95 \%$ confidence intervals $(\mathrm{CI})$.

\section{Results}

The genotypes and allele frequencies of FokI VDR gene polymorphism among prostate cancer and control participants are shown in table (1). The genotypes are in Hardy-Weinberg equation. There is no significant association of the VDR gene FokI gene polymorphism with prostate risk among prostate patients or healthy controls participants. The frequency of FF genotype was (30.7\%) for prostate cancer patients compared with (28\%) for healthy control. Ff genotype frequency in prostate cancer patients group was $(61.3 \%)$ compared with $(66 \%)$ for healthy control. ff genotype frequency was $(8.1 \%)$ in prostate patients group compared to $(6 \%)$ within the healthy control group (Table 1).

Our results (table 2 ) showed that the mean serum level of $25(\mathrm{OH}) \mathrm{D}$ for prostate patients $(7.7 \pm 0.44 \mathrm{ng} / \mathrm{ml})$ was significantly lower than the level in the control group (21.8

Table 1. Association of VDR Genotypic Frequencies among Prostate Cancer and Control Participants in Regard with Hardy-weinberg Equilibrium

\begin{tabular}{cccc}
\hline Genotype & Case n(\%) & Control n(\%) & P value \\
\hline FF & $38(30.7)$ & $28(28)$ & 0.719 \\
Ff & $76(61.3)$ & $66(66)$ & \\
Ff & $10(8.1)$ & $6(6)$ & \\
Allele & & & \\
F & $152(61.3)$ & $122(61)$ & 0.95 \\
F & $96(38.7)$ & $78(39)$ & \\
\hline
\end{tabular}

Table 2. Serum 25(OH)D Mean Levels among Prostate Cancer Patients and Control

\begin{tabular}{lccc}
\hline & $\mathrm{N}$ & $\mathrm{Mean} \pm \mathrm{SE} *(\mathrm{ng} / \mathrm{ml})$ & $\mathrm{p}$ value \\
\hline Prostate cancer patients & 124 & $7.7 \pm 0.44$ & $0.001 * *$ \\
Control & 100 & $21.8 \pm 0.56$ & \\
\hline
\end{tabular}

*SE: Standard error of the mean. **p-value $<0.05$ is considered significant 
The Fok1 Vitamin D Receptor Gene Polymorphism and 25(OH)D Levels and Prostate Cancer among Jordanian Men Table 3. Association between 25(OH)D Level and Prostate Cancer Risk

\begin{tabular}{lcccc}
\hline$(\mathrm{OH}) \mathrm{D}$ Status & Prostate Cancer Patients N=124 & Controls n=100 & OR & $95 \% \mathrm{CI}$ \\
\hline $25(\mathrm{OH}) \mathrm{D}$ less than $10.0 \mathrm{ng} / \mathrm{ml}$ & $86(69.35 \%)$ & $6(6.00 \%)$ & 35.45 & $(14.28-88.03)$ \\
$10.0 \leq 25(\mathrm{OH}) \mathrm{D} \geq 20 \mathrm{ng} / \mathrm{ml}$ & $34(27.42 \%)$ & $77(77.00 \%)$ & 0.11 & $(0.06-0.21)$ \\
$25(\mathrm{OH}) \mathrm{D}$ more than $20 \mathrm{ng} / \mathrm{ml}$ & $4(3.23 \%)$ & $17(17.00 \%)$ & 0.2 & $(0.05-0.50)$ \\
\hline
\end{tabular}

*Deficient: less than 20ng/ml; Insufficient: between 10 and 20ng/ml; Optimal: more than 20ng/ml

Table 4. Serum 25(OH)D Mean Levels (ng/ml) for Each FokI Genotypes

\begin{tabular}{|c|c|c|c|c|c|c|c|}
\hline \multicolumn{4}{|c|}{ Prostate Patients $(\mathrm{n}=124)$} & \multicolumn{3}{|c|}{ Control $(n=100)$} & \multirow[b]{2}{*}{ p-value } \\
\hline $\begin{array}{l}\text { VDR FokI } \\
\text { Genotype }\end{array}$ & $\mathrm{N}$ & Mean \pm Std $(\mathrm{ng} / \mathrm{ml})$ & p-value & $\begin{array}{l}\text { VDR FokI } \\
\text { Genotype }\end{array}$ & $\mathrm{N}$ & Mean \pm Std $(\mathrm{ng} / \mathrm{ml})$ & \\
\hline FF & 38 & $6.2 \pm 4.3$ & 0.036 & $\mathrm{FF}$ & 28 & $19.0 \pm 5.5$ & 0.002 \\
\hline $\mathrm{Ff}$ & 76 & $8.2 \pm 4.2$ & & $\mathrm{Ff}$ & 66 & $22.5 \pm 5.1$ & \\
\hline $\mathrm{ff}$ & 10 & $9.9 \pm 9.2$ & & $\mathrm{ff}$ & 6 & $26.3 \pm 6.5$ & \\
\hline
\end{tabular}

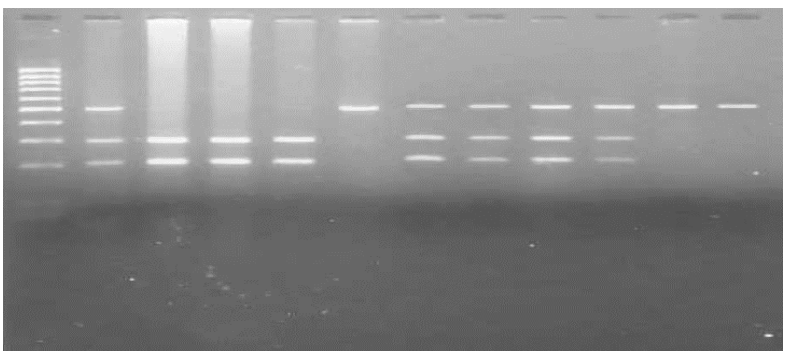

Figure 1. 2\% Agarose Gel Electrophoresis for the Genotypes After FokI Enzyme Digestion of the PCR Product. Lane 1: 50bp DNA ladder. Lanes 2, 7, 8, 9, and 10: Ff genotypes. Lane 6, 11, 12: FF genotype. Lanes 3, 4 and 5: ff genotypes

$\mathrm{ng} / \mathrm{ml} \pm 0.56)(\mathrm{p}$-value $=0.001)$.

The results of this study shows that there statistical significant difference in the mean 25(OH)D levels among $\mathrm{FF}, \mathrm{Ff}$ and $\mathrm{ff}$ genotypes within both prostate cancer patients $(\mathrm{p}=0.036)$ and control $(\mathrm{p}=0.002)$

\section{Discussion}

Vitamin D insufficiency affects almost $50 \%$ of the population worldwide. An estimated 1 billion people worldwide, across all ethnicities and age groups, have a vitamin D deficiency (Nair and Maseeh, 2012). Prostate cancer is one of the most common cancers among men, it is the second leading cause of cancer deaths worldwide (Siegel et al., 2013). Although it is less common in developing countries, its incidence and mortality rate is raised (Jemal et al., 2006). In Jordan and according to ministry of health at the Hashemite Kingdom ((www.moh. gov.jo)there were 179 prostate cancer cases accounting $3.7 \%$ of all Jordanian cancer cases. Prostate cancer ranked the sixth among Jordanian male cancers which accounted $(7.9 \%)$ of male cancers. Its etiology is unclear; however it may be related to ethnicity, environmental, genetics, hormonal and dietary factors (Tzonou et al., 1999; Lichtenstein et al., 2000)

The reason why VDR gene polymorphism has attracted attention because of the overall of anticancer effect of vitamin D itself. A number of studies have examined the role of VDR variants in prostate cancer with equivocal results ranging from statistically significant association
(Oakley-Girvanet al., 2004; Jemal et al., 2006), weak association (Hayes et al., 2005) to no association (Guo et al., 2013) between common VDR variants and prostate cancer. Our finding showed no significant association of VDR Fokl gene polymorphism with prostate cancer risk. This is consistent with many previous studies (Yin et al., 2009; Zhang and Shan, 2013; Yousaf et al., 2014) among different ethnic groups.

Eighty three percent of the control participants in this study are deficient/insufficient for vitamin $25(\mathrm{OH})$ $\mathrm{D}$ level. This high percentage is similar to the percentage observed by Atoum and Tchoporyan (2014) among Jordanians. Although Jordanian climate may offers sufficient sunlight, the observed considerable deficiency and insufficiency might be attributed to other factors such as high pigmentation of Middle Eastern population, working indoors most of the daytime and dietary style (Nair and Maseeh, 2012).This study also shows that $17 \%$ of control have optimal serum $25(\mathrm{OH}) \mathrm{D}$ level (more than $20 \mathrm{ng} / \mathrm{ml}$ ), while only $3 \%$ of prostate cancer patients are optimal. This study also shows that patients deficient in vitamin D (less than $10.0 \mathrm{ng} / \mathrm{ml}$ ) had 35 fold increased prostate cancer risk compared to control. While increasing circulatory $25(\mathrm{OH}) \mathrm{D}$ level by adequate exposure to sunlight or oral supplementation promote the prostate cells to convert $25(\mathrm{OH}) \mathrm{D}$ to 1 alpha $25(\mathrm{OH}) \mathrm{D} 2$ which has an antiproliferative effect in prostate cells (Donkena and Young, 2011). This finding shows that deficiency in $25(\mathrm{OH}) \mathrm{D}$ might participate in prostate cancer development and progression, and vitamin D level could be added as an additional factor to consider before ordering a biopsy for prostate cancer patients.

Our results showed significant difference in the mean of $25(\mathrm{OH}) \mathrm{D}$ level among various VDR Fokl genotype (FF, $\mathrm{Ff}$, ff) within the prostate and control groups. Consitant with our results, a prospective study observed that the Fokl gene polymorphism interacted with $25(\mathrm{OH}) \mathrm{D}$ and modified prostate cancer risk in the presence of low 25(OH)D status ( $\mathrm{Li}$ et al., 2007). On the other hand, $\mathrm{Xu}$ et al (2003) showed that presence of an F allele increased the risk of being diagnosed with more aggressive cancer because higher percentage of Gleason grade 4/5 is associated with worse prognosis. Huang et al (2006) suggested that the VDR FokI FF genotype increased the 
risk of early-onset prostate cancer, especially its more aggressive forms (Huang et al., 2006). Our data showed that FF genotype associate with the lowest $25(\mathrm{OH}) \mathrm{D}$ among both prostate cancer patients and control (6.2 and 19), respectively. The frequencies of the different Fokl genotypes vary widely across different population and ethnic groups most likely due to different population`s diverse genetic behavior and exposure to mutagens leading to mutations that can amplify infrequency in a population.

\section{References}

Atoum M, Tchoporyan MN (2014). Association between circulatory vitamin $\mathrm{D}$, Taq1 vitamin $\mathrm{D}$ receptor gene polymorphism and colorectal cancer risk among Jordanians. Asian Pac J Cancer Prev, 15, 7337-41.

Baker, AR, McDonnell DP, Hughes M, et al (1988). Cloning and expression of full-length cDNA encoding human vitamin D receptor. Proc Natl Acad Sci USA, 85, 3294-8.

Brown, AJ, Dusso A, Slatopolsky E (1999). Vitamin D. Am J Physiol, 277, 157-75.

Crofts La, Hancock MS, Morrison NA, Eisman JA (1998). Multiple promoters direct the tissue-specific expression of novel n-terminal variant human vitamin d receptor gene transcripts. Proc Natl Acad Sci USA, 95, 10529-34.

Donkena KV, Young C (2011). Vitamin D, sunlight and prostate cancer risk. Adv Prev Med, 281863, 13.

Grant WB. Vitamin D status: ready for guiding prostate cancer diagnosis and treatment. Clin Cancer Res, 20, 2241-3.

Gross, C, Stamey T, Hancock S and Feldman D (1998). Treatment of early recurrent prostate cancer with 1,25-dihydroxyvitamin D3 (calcitriol). J Urol, 159, 2035-9; 2039-40.

Guo Z, Wen J, Kan Q, et al (2013). Lack of association between vitamin D receptor gene FokI and BsmI polymorphisms and prostate cancer risk: an updated meta-analysis involving 21,756 subjects. Tumour Biol, 34, 3189-3200.

Habuchi T, Suzuki T, Sasaki R, et al (2000). Association of vitamin $\mathrm{D}$ receptor gene polymorphism with prostate cancer and benign prostatic hyperplasia in a Japanese population. Cancer Res, 60, 305-8.

Haussler MR, Whitfield GK, Haussler CA, et al (1998). The nuclear vitamin D receptor: biological and molecular regulatory properties revealed. J Bone Miner Res, 13, 325-49.

Huang SP, Huang CY, Wu WJ, et al (2006). Association of Vitamin D receptor Fok1 polymorphism with prostate cancer risk, Clinico-pathological features and recurrence of prostate specific antigen after radical prostatectomy. Int J Cancer, 119, 1902-7.

Hayes VM, Severi G, Padilla EJ, et al (2005). Genetic variants in the vitamin D receptor gene and prostate cancer risk. Cancer Epidemiol Biomarkers Prev, 14, 997-9.

Holt SK, Kwon EM, Peters U, Ostrander EA, Stanford JL (2009). Vitamin D pathway gene variants and prostate cancer risk. Cancer Epidemiol Biomarkers Prev, 18, 1929-33.

Holund B (1980). Latent prostatic cancer in a consecutive autopsy series. Scand J Urol Nephrol, 14, 29-35.

Hughes, MR, Malloy PJ, Kieback DG, et al (1988). point mutations in the human vitamin $\mathrm{d}$ receptor gene associated with hypocalcemic rickets. Science 242, 1702-5.

Ingles, SA, Coetzee GA, Ross RK, et al (1998). Association of prostate cancer with vitamin D receptor haplotypes in African-Americans. Cancer Res, 58, 1620-3.

Jemal A, Siegel R, Ward E, et al (2006) CA Cancer J Clin, 56, 106-30.

Li H, Stampfer MJ, Hollis JB, et al (2007). A prospective study of plasma vitamin D metabolites, vitamin D receptor polymorphisms, and prostate cancer. PLoS Med, 4, 103 .

Li XY, Boudjelal M, Xiao JH, et al (1999). 1,25-Dihydroxyvitamin D3 increases nuclear Vitamin D3 receptors by blocking ubiquitin/proteasome-mediated degradation in human skin." Mol Endocrinol 13, 1686-94.

Lichtenstein P, Holm NV, Verkasalo PK, et al (2000). Skytthe A and Hemminki K. Environmental and heritable factors in the causation of cancer--analyses of cohorts of twins from Sweden, Denmark, and Finland. N Engl J Med, 343, 78-85.

Luong, KV and Nguyen LT (2010). The beneficial role of vitamin $\mathrm{d}$ and its analogs in cancer treatment and prevention. Crit Rev Oncol Hematol, 73, 192-201.

Miller GJ, Stapleton GE, Ferrara JA, et al (1992). The human prostatic carcinoma cell line lncap expresses biologically active, specific receptors for 1 alpha,25-dihydroxyvitamin D3. Cancer Res, 52, 515-20.

Nair RI, Maseeh A (2012). Vitamin D the sun shine vitamin. $J$ Pharmacol Pharmacother. 3, 118-126.

Nwosu V, Carpten J, Trent JM, Sheridan R (2001). Heterogeneity of genetic alterations in prostate cancer: evidence of the complex nature of the disease. Hum Mol Genet, 10, 2313-8.

Oakley-Girvan I, Feldman D, Eccleshall TR, et al (2004). Risk of Early-onset prostate cancer in relation to germ line polymorphisms of the vitamin D receptor. Cancer Epidemiol Biomarkers Prev, 13, 1325-30.

Parkin, DM, Bray FI, Devesa SS (2001). Cancer burden in the Year 2000. The global picture. Eur J Cancer, 37, 4-66.

Peehl DM, Skowronski RJ, Leung GK, (1994). Antiproliferative effects of 1,25-dihydroxyvitamin D3 on primary cultures of human prostatic cells. Cancer Res, 54, 805-10.

Polek, TC, Weigel NL. Vitamin D and prostate cancer (2002). $J$ Androl, 23, 9-17.

Saijo T, It M, Takeda E, et al (1991). A unique mutation in the vitamin $d$ receptor gene in three japanese patients with vitamin d-dependent rickets type ii: utility of single-strand conformation polymorphism analysis for heterozygous carrier detection. Am J Hum Genet, 49, 668-73.

Siegel R, Naishadham D, Jemal A (2013). Cancer statistics, 2013 CA Cancer J Clin, 63, 11-30.

Tzonou A, Signorello LB, Lagiou P, et al (1999). Diet and cancer of the prostate: a case-control study in Greece. Int $J$ Cancer, 80, 704-8.

Wu-Wong JR (2007). Vitamin D receptor: a highly versatile nuclear receptor. Kidney Int, 72, 237-9.

Xu J, Zheng SL, Komiya A, et al (2003). Common sequence variants of the macrophage scavenger receptor 1 gene are associated with prostate cancer risk. Am J Hum Genet, 72, 208-12.

Yin, M, Wei S and Wei Q (2009). Vitamin D receptor genetic polymorphisms and prostate cancer risk: A meta-analysis of 36 published studies. Int J Clin Exp Med, 2, 159-75.

Yousaf N, Afzal S, Hayat T,et al (2014). Association of vitamin $\mathrm{D}$ receptor gene polymorphism with prostate cancer risk in Pakistani population. Asian Pac J Cancer Prev, 15, 10009-13.

Yu, S. and Cantorna MT (2011). Epigenetic reduction in invariant nkt cells following in utero vitamin d deficiency in mice. $J$ Immunol, 186, 1384-90.

Zhang X, Ho SM (2011). Epigenetics meets endocrinology. $J$ Mol Endocrinol, 46, 11-32.

Zhang Q, Shan Y (2013). Genetic polymorphism of vitamin D receptor and risk of prostate cancer: a meta -analysis. $J$ Boun, 18, 961-9. 